\title{
Direct Determination of Total Mercury in Mineral Coal Samples
}

\author{
Juliana M. Silva (IC), Fernanda N. Costa (PG), Anne H. Fostier (PQ)
}

\begin{abstract}
Mercury is recognized as a potent neurotoxic substance and it is included in the list of Persistent Toxic Substances ${ }^{1}$. It is estimated that anthropic emissions of atmospheric $\mathrm{Hg}$ are around 2,000 $\mathrm{t}$ year ${ }^{-1}$, which $25 \%$ is originated from coal burning ${ }^{2}$. In Brazil, MMA calculated emissions of $1.0 \mathrm{t}$ of $\mathrm{Hg}$ year ${ }^{-1}$ due to coal burning in thermoelectric plants ${ }^{3}$. However, data about $\mathrm{Hg}$ concentrations in Brazilian coal are scarce. This work aimed at the determination of $\mathrm{Hg}$, based on thermal decomposition, amalgamation and detection by AAS. This analytical method of solids is efficient, free of sample preparation and avoids loss and contamination. The influence of the analyzed mass sample and the matrix effect has been evaluated. Method validation has been performed by the mean of analytical curve linearity, accuracy, precision, limit of detection and limit of quantification. The validated method was applied in coal samples from different regions of Brazil and of the world and the results showed mercury concentration values close to the values found in the literature.
\end{abstract}

Key words: Mercury, Mineral Coal, Direct Analyzer.

\section{Introduction}

The aim of this work was to optimize and validate a method for total $\mathrm{Hg}$ determination in coal using a Direct Mercury Analyzer (DMA-80, TRICELL, Milestone, Italy).

\section{Results and Discussion}

The analytical curve presented good linearity between 0.1 and $20 \mathrm{ng}$, with a correlation coefficient $\left(R^{2}\right)>0.9986$ in Cell 0 and Cell 1 , and residual sum of squares of $3.42 \cdot 10^{-4}$ e $2.03 \cdot 10^{-3}$ respectively for both cells. It was performed a Student's t-test and it was not verified significant difference between the angular coefficients of aqueous solutions curve and curve built with standard addition in coal sample $(p>0.05)$. The method was considered exact, with recovery of $107 \%$ of the certificate value (Coal SRM 1632d). An addition and recovery study confirmed the method accuracy, being verified recoveries of $95 \%$ and $101 \%$, for $\mathrm{Hg}$ additions of $1 \mathrm{ng}$ and $5 \mathrm{ng}$, respectively. Precision is related with sample granulometry. The decrease of the granulometry improves the precision, due to a better homogenization of the sample. It was obtained a Relative Standard Deviation $>39 \%$ and $<6 \%$, for granulometry $>500$ and $<200 \mu \mathrm{m}$, respectively. In mass interval between 5 and $30 \mathrm{mg}$, it was not found significant variation (Student's t-test, $p>$ 0.05) of the $\mathrm{Hg}$ concentration. The limit of detection and quantification were $0.017 \mathrm{ng}$ and $0.059 \mathrm{ng}$, respectively. The validated method was applied in mineral coal sample from Brazil, Canada, Colombia, Mozambique and USA. The $\mathrm{Hg}$ concentration for Brazilian samples ranged of
0.132 to $0.293 \mathrm{mg} \mathrm{kg}^{-1}$ and the $\mathrm{Hg}$ concentration of all the regions was of 0.056 to $0.293 \mathrm{mg} \mathrm{kg}^{-1}$.

\section{Conclusions}

The overall $\mathrm{Hg}$ concentrations obtained in this work are in accordance with previous data $(0.02$ to $\left.1 \mathrm{mg} \mathrm{kg}^{-1}\right)^{4}$ and $\mathrm{Hg}$ concentrations found for Brazilian samples are in the range of 0.05 to 0.8 reported by Pires et al. ${ }^{5}$ for Brazilian coal. The analysis of more coal samples will allow the formation of a more consistent database. This data is necessary to calculate $\mathrm{Hg}$ emission factors of thermoelectric plants.

\section{Acknowledgement}

CNPq, CAPES, FAPESP.

\footnotetext{
${ }^{1}$ UNEP (United Nation Environmental Program), Mercury, time to act, UNEP, Geneva, Switzerland, 2013a, 44 p.

${ }^{2}$ UNEP, Global Mercury Assessement: sources, emissions, releases and environmental transport, 2013b.

${ }^{3}$ MMA (Ministério do Meio Ambiente), Diagnóstico Preliminar sobre o Mercúrio no Brasil, Ministério do Meio Ambiente, Brasilia, Brasil, 2013, 106p.

${ }^{4}$ Swaine, D.J., Trace Elements in Coal. Butterworths, London, 1990. (cited by Pires, M.; Querol, X., Characterization of Candiota (South Brazil) coal and combustion by-product, International Journal of Coal Geology, 2004, 60, 57-72.)

${ }^{5}$ Pires, M.; Fiedler, H.; Teixeira, E. C., Dstribuição geoquímica de elementos traço no carvão: modelamento e aspectos ambientais. In: E. C. Teixeira \& M. Pires (Eds.) Carvão e Meio Ambiente. FEPAM/PUCRS/UFSC, 2002, 450p..
} 